\title{
CORRESPONDENCE
}

\section{SURGERY OF ENTROPION}

\section{To the Editorial Committee of the British JouRnal of OPHTHALMOLOGY}

SIRS,--In October, 1966, a letter was published from Dr. A. Urrets-Zavalía, Jr., stating that Dr. J. L. S. Smith and I, in our paper on "The Mechanics and Histology of Senile Entropion", gave "good support to the lid through the horizontal traction exerted by two triangular flaps", an operation which he himself had previously described (Urrets-Zavalía, 1959). On the contrary, instead of this procedure, largely for cosmetic reasons, I simply do a Z-plasty on the skin to remove a scar perpendicular to the lid-margin, in line with my usual practice in certain circumstances; there is also the all-important difference in the shape of the full-thickness segment which is excised from the lid. I must make it clear that, in view of our researches, I do not think that the lid-margin should be shortened in cases of senile entropion and I abandoned all procedures of this type in 1964.

Yours faithfully,

UNIVERSTTY DePARTMENT OF OPHTHALMOLOGY,

\section{R. Dalgleish}

ROYAL EYE HOSPITAL,

OXFORD RoAD, MANCHESTER 13.

April 10, 1967.

\section{To the Editorial Committee of the BRITISH JouRNAL OF OPHTHALMOLOGY}

SIRS,- -Whatever Mr. Dalgleish's views may be on the matter of whether or not a full-thickness lid segment should be excised in those cases of senile entropion in which the tissues are stretched, the facts remain that:

(a) In the article referred to, Mr. Dalgleish states that he has done just that in many of the patients with this condition who came to be treated by him;

(b) In a more recent paper entitled "Reconstructive Lid Surgery" (Dalgleish, 1966), he advocates that a central resection be carried out in the case of benign and premalignant lid tumours;

(c) He feels that in both these situations the resulting defect should be repaired by breaking up the vertical suture line with two additional cuts and by transposing the flaps.

Now this is the operation which I described originally, in which the removal of a wedge of the lower lid-which may be shaped like a V, an U, or a combination of both-is followed by a Zplasty. The contour of the coloboma may of course vary from case to case and to my mind is only of secondary importance. As a matter of fact, $I$ once even thought of christening the procedure a $\mathrm{U}-\mathrm{Z}$; if I didn't, it was in part because this would have smacked too much of a monogram.

\section{Yours faithfully,}

DePaRTMENT OF OPHTHALMOLOGY,

Alberto UrRets-Zavalía, Jr.

Universidad de Córdoba Medical School,

Córdoba, Argentina.

May 4, 1967.

\section{REFERENCES}

Dalgleish, R. (1966). Trans. ophthal. Soc. U.K., 86, 579. and SMith, J. L. S. (1966). Brit. J. Ophthal., 50, 79.

UrRets-Zavalfa, A. (1959). Ibid., 43, 521. (1966). Ibid., 50, 614.

Little is gained by a series of polemical letters and in the total of knowledge priority of ideas is a secondary matter. This correspondence is therefore closed-Editor. 